\title{
Perlindungan Hukum terhadap Disabilitas dalam Memenuhi Hak Mendapatkan Pendidikan dan Pekerjaan
}

\author{
Jazim Hamidi \\ Fakultas Hukum Universitas Brawijaya \\ Jln. Veteran, Ketawanggede, Kec. Lowokwaru, Kota Malang, Jawa Timur 65145 \\ jazimub@gmail.com
}

\begin{abstract}
As a law-based country, it becomes a must for Indonesia to protect the disability; one of constitutional rights as regulated in Article 28 I Sentence (2) Constitution 1945 of Indonesia Republic. This research is to study: first, the form of the legal protection in an attempt to fulfil the right for getting education and job for the disabilities; second, the formulation of the affirmative action policy for the accessibility in education and job for the disabilities in Indonesia. the typology of this research is the dogmatic legal research addressed to observe and formulate the legal argumentation through the analysis on the core of the issues. The technique of collecting the legal material was done through the library research and the approach used was the statute approach that is by analysing the valid legal regulation regarding the disabilities. This research concluded that first; the government tends to give the legal protection discriminatively for those with disabilities to obtain the proper education and job. Second, there was a bias in legal norm in the regulation on the accessibility of education and job; thus there is a need of legal renewal in the form of affirmative action policy on accessibility of education and job for the disabilities including: 1) completing (making something better); 2) changing to make it much better and 3) doing something unavailable before.
\end{abstract}

Keywords: Legal protection, disabilities, rights to have education and work and living properly

\section{Abstrak}

Indonesia sebagai negara hukum merupakan suatu keharusan melindungi disabilitas, salah satu hak konstitusional (constitutional right) sebagaimana yang diatur dalam Pasal 28 I ayat (2) UUD NRI Tahun 1945. Permasalahan dalam penelitian ini, pertama, bagaimanakah bentuk perlindungan hukum dalam upaya pemenuhan hak untuk mendapatkan pendidikan dan pekerjaan bagi disabilitas? Kedua, bagaimana formulasi kebijakan affirmative action untuk aksesibilitas pekerjaan bagi disabilitas di Indonesia? Tipologi penelitian ini adalah penelitian hukum normatif (dogmatic) yang ditujukan untuk menemukan dan merumuskan argumentasi hukum, melalui analisis terhadap pokok permasalahan. Teknik pengumpulan bahan hukumnya dilakukan dengan studi kepustakaan. Pendekatan yang digunakan dalam penelitian ini adalah pendekatan perundang-undangan (statute approach), yaitu dengan menelaah aturan hukum yang berlaku terkait dengan disabilitas. Penelitian ini menyimpulkan pertama, pemerintah terkesan mendiskriminasikan penyandang disabilitas untuk memperoleh pendidikan tinggi layaknya orang yang normal. Di samping itu, terdapat kekosongan dalam peraturan yang mengatur tentang aksesibilitas pekerjaan. Kedua, pembaharuan hukum aksesibilitas pekerjaan bagi disabilitas meliputi: 1) Menyempurnakan (membuat sesuatu yang lebih baik); 2) mengubah agar jauh lebih baik; 3) Mengadakan sesuatu yang sebelumnya belum ada.

Kata-kata Kunci: Perlindungan hukum, disabilitas, hak mendapatkan pendidikan dan pekerjaan, dan hidup secara wajar 


\section{Pendahuluan}

Setiap orang berpotensi menjadi disabilitas ${ }^{1}$. Seseorang dapat menjadi disabilitas bukan hanya karena kelainan dalam kandungan, namun disabilitas juga dapat terjadi pada anak-anak, remaja, dewasa, hingga orang tua. Setiap orang dapat mengalami kecelakaan di jalan raya, kecelakaan kerja, maupun menjadi korban bencana alam. Hal tersebut dapat menyebabkan seseorang menjadi penyandang disabilitas. Penyandang disabilitas adalah mereka yang memilikipenderitaan fisik, mental, intelektual, atau sensorik dalam jangka waktu lama dimana interaksi dengan berbagai hambatan dapat menyulitkan partisipasi penuh dan efektif dalam masyarakat berdasarkan kesetaraan dengan yang lainnya. ${ }^{2}$ Berikut merupakan tabel prevalensi disabilitas di dunia:

Tabel 1

Estimasi Prevalensi Disabilitas Berdasarkan Estimasi Global Burden of Disease Tahun 2004

\begin{tabular}{|c|c|c|c|c|c|c|c|c|}
\hline \multirow[b]{3}{*}{$\begin{array}{l}\text { Jenis Kelamin/ } \\
\text { Umur }\end{array}$} & \multicolumn{8}{|c|}{ Presentase } \\
\hline & \multirow[b]{2}{*}{$\stackrel{\Xi}{\Xi}$} & \multirow[b]{2}{*}{ 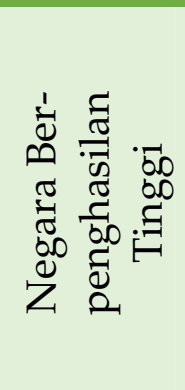 } & \multicolumn{6}{|c|}{$\begin{array}{c}\text { Negara Berpenghasilan Menengah dan } \\
\text { Rendah, Regional } \mathrm{WHO}\end{array}$} \\
\hline & & & 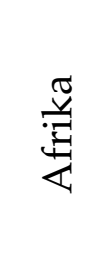 & $\frac{\pi}{\stackrel{\pi}{\Xi}}$ & 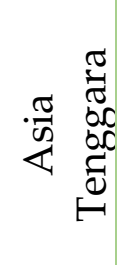 & 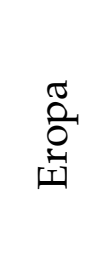 & 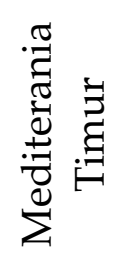 & 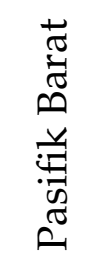 \\
\hline \multicolumn{9}{|c|}{ Disabilitas Sedang dan Parah } \\
\hline \multicolumn{9}{|c|}{ Laki-laki dan Perempuan } \\
\hline 0-14 Tahun & 5,1 & 2,8 & 6,4 & 4,6 & 5,2 & 4,2 & 5,2 & 5,3 \\
\hline 15-59 Tahun & 14,9 & 12,4 & 19,1 & 14,6 & 16,3 & 14,3 & 15,5 & 13,7 \\
\hline$\geq 60$ Tahun & 46,1 & 36,8 & 53,3 & 44,3 & 58,8 & 41,4 & 53,7 & 46,7 \\
\hline$\geq 15$ Tahun & 19,4 & 18,3 & 22,0 & 18,3 & 21,1 & 19,5 & 19,1 & 18,1 \\
\hline Semua umur & 15,3 & 15,4 & 15,3 & 14,1 & 16,0 & 16,4 & 14,0 & 15,0 \\
\hline \multicolumn{9}{|c|}{$\begin{array}{l}\text { Catatan: Negara berpenghasilan tinggi adalah negara dengan GNI perkapita sebesar USD 10,066 } \\
\text { atau lebih sesuai estimasi Bank Dunia. Negara dengan penghasilan menengah dan rendah } \\
\text { mempunyai pendapatan perkapita kurang dari USD } 10.066 \text { (sesuai estimasi Bank Dunia). } \\
\text { Sumber: World Report on Disability, WHO } 2011^{3}\end{array}$} \\
\hline
\end{tabular}

${ }^{1}$ M. Syahbuddin Latief, Jalan Kemanusiaan, Panduan untuk Memperkuat Hak Asasi Manusia,Lapera Pustaka Utama, Yogyakarta, 1999, hlm. 40

IIbid., hlm. 50

${ }^{3}$ World Report on Disability, WHO 2011 dalam Kementrian Kesehatan RI, Buletin Jendela Data dan Informasi Kesehatan: Situasi Penyandang Disabilitas, 2014, hlm. 3-4. 
Di Indonesia, jaminan Hak Asasi Manusia tercantum dalam Pasal 28A-28J Undang-Undang Dasar Negara Republik Indonesia 1945 (selanjutnya disebut UUD NRI Tahun 1945). ${ }^{4}$ Pencantuman hak asasi manusia dalam UUD NRI Tahun 1945, secara resmi telah menjadikannya sebagai hak konstitusional setiap warga negara atau "constitutional right". 5 Dengan adanya hak konstitusonal, setiap warga negara memiliki jaminan konstitusional atas setiap hak-haknya yang termuat dalam UUD NRI Tahun 1945. Jaminan tersebut dapat berupa pengejawantahan hak konstitusonal ke dalam undang-undang atau penyediaan ruang gugatan konstitusional ke Mahkamah Konstitusi jika ada pelanggaran terhadap hak-hak warga negara.

Pasal-Pasal tersebut mengandung arti jelas bahwa, jika ada warga negara tidak mendapatkan haknya atas pendidikan dan pekerjaan, maka warga negara itu bisa menuntut haknya kepada negara. Sebaliknya, jika ada warga negara tidak melaksanakan kewajiban pendidikannya, negara berhak mengenakan sanksi kepada yang bersangkutan. Berangkat dari kete Wintuan di atas, bisa ditarik benang merah bahwa negara menjamin kepada semua warga negaranya tanpa terkecuali untuk memperoleh pendidikan dan pekerjaan layak.

Kenyataannya dewasa ini, penyandang disabilitas masih mengalami berbagai tindakan diskriminasi, terutama terkendala dengan persyaratan "sehat jasmani dan rohani" yang selalu menjadi salah satu syarat umum yang mutlak dimiliki setiap orang. Sebut saja dalam penerimaan mahasiswa baru di Universitas, syarat ini akan selalu muncul sebagai salah satu syarat umum yang harus dimiliki oleh calon mahasiswa. Pun dengan penerimaan pekerjaan, syarat umum yang lazim dipersyaratkan dalam penerimaan calon pekerja juga "sehat jasmani dan rohani". Bahkan, dalam persyaratan mendaftar menjadi seorang wakil rakyat, seorang bakal calon juga haruslah "sehat jasmani dan rohani".

${ }^{4}$ Pasal-Pasal tersebut dapat dikategorikan menjadi empat kelompok ketentuan hak asasi manusia. Ketentuan tersebut antara lain adalah kelompok hak-hak sipil; kelompok hak politik, sosial, ekonomi dan budaya; kelompok hak khusus dan hak atas pembangunan; kelompok yang mengatur mengenai tanggung jawab negara dan kewajiban asasi manusia. Jimly Asshiddiqie, Pengantar Ilmu Hukum Tata Negara Jilid 2, Sekretaris Jenderal dan Kepaniteraan Mahkamah Konstitusi, Jakarta, 2006, hlm. 105.

${ }^{5}$ Bandingkan dengan Zulkarnain Ridlwan, "Perlindungan Hak-hak Konstitusional Penyandang Disabilitas (Rights of Persons with Disabilities)", dimuat dalam Fiat Justitia Jurnal Ilmu Hukum, Volume 7 No. 2, Mei - Agustus 2013, hlm. 231 dan 233. 
Paradigma masyarakat, terhadap kaum disabilitas seringkali diibaratkan sebagai ketidakmampuan seseorang secara medis, sehingga disabilitas dianggap sebagai orang sakit yang selalu membutuhkan pertolongan dan tidak dapat mengenyam pendidikan, apalagi bekerja seperti manusia pada umumnya. Kelompok konservatif bahkan mengatakan bahwa keadaan disabilitas adalah kehendak Tuhan, oleh karena itu manusia hendaknya hanya pasrah saja dalam menghadapi kondisi tersebut. Kaum disabilitas seringkali disebut sebagai orang yang tidak beruntung. Disabilitas haruslah dipandang sebagai ketidakmampuan sosial, sehingga setiap orang dapat berpartisipasi dalam upaya melindungi kaum minoritas tersebut, tentu saja pendekatan sosial merupakan jalan utama yang dapat ditempuh.

Secara filosofis para pendiri bangsa telah menggariskan cita-cita luhurnya, dalam memberikan perlindungan dan jaminan hukum yang mutlak bahwa pendidikan dan pekerjaan harus bisa dirasakan dan dinikmati oleh setiap warga negara. Untuk mencapai amanah tersebut strategi yang sangat penting dan harus dilaksananakan adalah membuat perlindungan hukum atas pemenuhan hak atas pendidikan dan pekerjaan untuk setiap warga negara Indonesia, tanpa pengecualian, melalui suatu sistem perlindungan hukum berdasarkan Pancasila dan UUD NRI Tahun 1945.

\section{Rumusan Masalah}

Berdasarkan hal tersebut di atas, kajian ini mengangkat permasalahan: Pertama, bagaimanakah bentuk perlindungan hukum dalam upaya pemenuhan hak untuk mendapatkan pendidikan dan pekerjaan bagi disabilitas? Kedua, bagaimana formulasi kebijakan affirmative action untuk aksesibilitas di bidang pendidikan dan pekerjaan bagi disabilitas Indonesia?

\section{Tujuan Penelitian}

Adapun tujuan penelitian ini adalah pertama, untuk mengetahui bentukbentuk perlindungan hukum dalam upaya pemenuhan hak untuk mendapatkan pendidikan dan pekerjaan bagi para penyandang disabilitas; kedua, mencari 
formulasi kebijakan affirmative action untuk aksesibilitas di bidang pendidikan dan pekerjaan bagi penyandang disabilitas.

\section{Metode Penelitian}

Sesuai dengan latar belakang, rumusan masalah, dan tujuannya, tipologi dalam penelitian ini adalah penelitian hukum normatif (dogmatic legal research) yang ditujukan untuk menemukan dan merumuskan argumentasi hukum, melalui analisis terhadap pokok permasalahan. Teknik pengumpulan bahan hukumnya dilakukan dengan studi kepustakaan. Pendekatan yang digunakan dalam penelitian ini meliputi: Pertama, pendekatan perundang-undangan (statute approach), yaitu dengan menalaah aturan hukum yang berlaku terkait dengan disabilitas. Wawancara secara terbatas dilakukan sebagai penunjang dan untuk mempertajam analisis normatifnya

\section{Hasil Penelitian dan Pembahasan}

Perlindungan Hukum dalam Pemenuhan Hak untuk Mendapatkan Pendidikan bagi Penyandang Disabilitas

Penjabaran UUD NRI 1945 yang sudah dilakukan negara terhadap penyandang disabilitas dalam hal pendidikan bagi penyandang disabilitas dan juga mengenai kebijakan dasar penyelenggaraan pendidikan nasional tentunya dapat dilihat di dalam Pembukaan UUD 45 alinea keempat, yang masuk dalam satu kesatuan integral tujuan negara, yaitu mencerdaskan kehidupan bangsa. Hal ini berarti secara tegas negara Republik Indonesia mengakui hak asasi manusia atas pendidikan. Oleh sebab itu, negara wajib melaksanakan pendidikan nasional, yang diatur dalam Pasal 31 ayat (1) dan (2) UUD NRI 45. Pasal 31 ayat (1) berisi: "Tiaptiap warga negara berhak untuk mendapat pengajaran"; dan ayat 2 berisi: "Pemerintah mengusahakan dan menyelenggarakan satu sistem pengajaran nasional, yang diatur dengan undang-undang".

Ketentuan Pasal 31 ayat (1) UUD NRI 1945 tidak membatasi siapa saja yang mendapatkan pendidikan, yang terpenting ialah warga negara dan berkependudukan di Indonesia. Tidak ada pembatasan terhadap orang yang kemampuan yang sama pada umumnya maupun bagi penyandang disabilitas karena semuanya layak menerima pendidikan dan dijamin oleh negara. 
Penjabaran terhadap pendidikan bagi penyandang disabilitas dalam UndangUndang Republik Indonesia Nomor 2 Tahun 1989 tentang Sistem Pendidikan Nasional Pasal 8 ayat (1) menjelaskan bahwa setiap warga negara yang memiliki kelainan fisik dan/atau mental berhak memperoleh pendidikan luar biasa, dan juga Pasal 11 ayat (1) menjelaskan terhadap jenjang pendidikan penyandang disabilitas, pendidikan penyandang disabilitas terhadap jenis pendidikan yang termasuk jalur pendidikan formal yaitu sekolah. Terdiri dari pendidikan umum, pendidikan kejuruan, pendidikan keagamaan, pendidikan akademik dan pendidikan professional. Pasal 11 ayat (4) menjelaskan klasifikasi penyandang disabilitas, yaitu pendidikan luar biasa merupakan pendidikan yang khusus diselenggarakan untuk peserta didik yang menyandang kelainan fisik dan/atau mental. Mengenai klasifikasi tingkatan pendidikan di Indonesia terdapat di Pasal 15 ayat (2) yang berisi pendidikan menengah terdiri dari pendidikan umum, pendidikan kejuruan, pendidikan luar biasa, pendidikan kedinasan, dan pendidikan keagamaan ${ }^{6}$.

Peraturan pelaksanaan terhadap Undang-Undang Republik Indonesia Nomor 2 Tahun 1989 Tentang Sistem Pendidikan Nasional terdapat dalam Peraturan Pemerintah Republik Indonesia Nomor 72 Tahun 1991 Pasal 1 ayat (1) menjelaskan bahwasanya:"pendidikan luar biasa adalah pendidikan yang khusus diselenggarakan bagi peserta didik yang menyandang kelainan fisik dan/atau mental". Sedangkan ayat 2 menjelaskan tentang satuan pendidikan luar biasa yaitu sekolah yang menyelenggarakan pendidikan luar biasa, sedangkan ayat 5 berisi: "bahwasanya siswa ialah peserta didik pada sekolah dasar luar biasa, sekolah lanjutan tingkat pertama luar biasa dan sekolah menegah luar biasa". ${ }^{7}$

Perjalanan terhadap pengaturan pendidikan bagi penyandang disabilitas terus berlanjut, sebelum reformasi 1998 terdapat 2 pengaturan bagi pendidikan penyandang disabilitas, yaitu Undang-Undang Nomor 2 Tahun 1989 tentang Sistem Pendidikan Nasional dan juga Undang-Undang Nomor 4 Tahun 1997 tentang Penyandang Cacat. Undang-Undang Penyandang Cacat Nomor 4 Tahun 1997 Pasal 6

6 Undang-Undang Republik Indonesia Nomor 2 Tahun 1989 tentang Sistem Pendidikan Nasional Lembaran Negara Tahun 1989 Nomor 6, Tambahan Lembaran Negara Nomor 3390

7 Peraturan Pemerintah Republik Indonesia Nomor 72 Tahun 1991 tentang Pendidikan Luar Biasa 
angka 1 menjelaskan "pendidikan penyandang cacat merupakan satuan jalur, jenis dan jenjang pendidikan".

Penjabaran terhadap amanat UUD NRI 1945 terhadap pendidikan yang dikhususkan bagi penyandang disabilitas terus berlanjut setelah reformasi 1998. Satu Tahun setelah masa-masa sulit negara ini dilanda krisis dan minimnya kepercayaan terhadap negara pemerintah mengeluarkan Undang-Undang Republik Indonesia tentang Hak Asasi Manusia untuk mengembalikan kepercayaan masyarakat kepada pemerintah. Bagi penyandang disabilitas pengaturantentang hak asasi manusia ini merupakan angin segar, karena Pasal 12 menjelaskan: "setiap orang berhak atas perlindungan bagi pengembangan pribadinya, untuk memperoleh pendidikan, mencerdaskan dirinya, dan meningkatkan kualitas hidupnya agar menjadi manusia yang beriman, bertaqwa, bertanggungjawab, berakhlak mulia, bahagia, dan sejahtera sesuai dengan hak asasi manusia".

Pasal 42 Undang-Undang Nomor 39 Tahun 1999 menyatakan: "setiap warga Negara yang berlanjut, cacat fisik dan atau cacat mental memperoleh perawatan, pendidikan, pelatihan, dan khusus atas biaya Negara, untuk menjamin kehidupan yang layak sesuai dengan martabat kemanusiaannya, meningkatkan rasa percaya diri, dan kemampuan berpartisipasi dalam kehidupan bermasyarakat, berbangsa, dan bernegara".

Peran demokrasi dan juga perubahan amandemen terhadap pengaturan Hak asasi manusia dan pemenuhan hak terhadap pengembangan diri dalamhal pendidikan bagi penyandang disabilitas terdapat di dalam Undang-Undang nomor 20 Tahun 2003 tentang Sistem Pendidikan Nasional Jo Undang-Undang nomor 2 Tahun 1989 yang menjelaskan dari Pasal 1 angka 1 yang berisi: "pendidikan adalah usaha sadar dan terencana untuk mewujudkan suasana belajar dan proses pembelajaran agar peserta didik secara aktif mengembangkan potensi dirinya untuk memiliki kekuatan spiritual keagamaan, pengendalian diri, kepribadian, kecerdasan, akhlak mulia, serta keterampilan yang diperlukan dirinya masyarakat, bangsa dan negara". Pasal 32 ayat (1) Undang-Undang No. 20 Tahun 2003 mengenai pendidikan khusus, yang berisi: "Pendidikan khusus adalah pendidikan bagi peserta didik yang memiliki tingkat 
kesulitan dalam mengikuti proses pembelajaran karena kelainan fisik emosional, mental, sosialdan/atu memiliki potensi kecerdasan dan bakat istimewa". ${ }^{8}$

Undang-Undang Sistem Pendidikan Nasional tersebut telah memiliki kemajuan mengenai pengaturan pendidikan bagi penyandang disabilitas. Tetapi pengaturan terhadap penjabaran amanat UUD NRI 1945 mengenai pendidikan bagi penyandang disabilitas ini berlanjut dengan banyaknya peraturan maupun kebijakan yang mengatur pendidikan bagi penyadang disabilitas.

Pendidikan merupakan salah satu hak yang diberikan kepada setiap orang dan juga kepada para penyandang disabilitas yang mana telah dijamin oleh pemerintah sebagai bentuk tanggungjawab negara. Undang-Undang Nomor 20 Tahun 2003 tentang Sistem Penididikan Nasional sudah memiliki beberapa aturan terkait tentang hak dan kewajiban bagi para penyandang disabilitas. Dijelaskan pada Pasal 5 ayat (1) bahwa: "setiap warga negara mempunyai hak yang sama untuk memeperoleh pendidikan yang bermutu". Pasal 5 ayat (2) bahwa: "seluruh warga negara dengan kelainan fisik, emosional, mental, intelektual, atau sosial berhak memeroleh pendidikan khusus".

Keluarnya Undang-Undang Nomor 20 Tahun 2003 tentang Sistem Pendidikan Nasional menjadi jaminan kepada pemerintah untuk mengeluarkan kebijakan baru bagi penyandang disabilitas dengan metode inklusif (Penyatuan), Peraturan Menteri Pendidikan Tahun 70 Tahun 2009 tentang pendidikan inklusif menjadi salah satu cara yang dilakukan pemerintah untuk memenuhi hak bagi penyandang disabilitas. Peraturan menteri pendidikan Tahun 70 Tahun 2009 tentang pendidikan inklusif menjelaskan defines di poin (a) menimbang: "bahwa peserta didik yang mempunyai kelainan dan mempunyai potensi kecerdasan dan/atau bakat istimewa perlu mendapatkan layanan pendidikan yang sesuai dengan kebutuhan dan hak asasinya". Pasal 1 berisi: "bahwa yang dimaksud dengan pendidikan inklusif adalah sistem penyelenggaraan pendidikan yang memberikan kesempatan kepada semua peserta didik yang memiliki kelainan dan memiliki potensi kecerdasan dan/atau bakat istimewa untuk mengikuti pendidikan atau pembelajaran dalam satu lingkungan pendidikan secara bersama sama dengan peserta didik pada umumnya". Sedangkan Pasal 2 ayat (1) berisi:

\footnotetext{
${ }^{8}$ Undang-Undang Nomor 20 Tahun 2003 tentang Sistem Pendidikan Nasional
} 
"pemberikan kesempatan yang seluas-luasnya kepada semua peserta didik yang memiliki kelainan fisik, emosional, mental, dan sosial atau memiliki potensi kecerdasan dan/atau bakat istimewa untuk memperoleh pendidikan yang bermutu sesuai dengan kebutuhan dan kemampuannya".

Pendidikan inklusif merupakan sebuah strategi yang bertujuan untuk mengurangi, bahkan menghilangkan batasan atau hambatan dalam mengakses pendidikan bagi anak penyandang disabilitas. Selama ini seringkali anak penyandang disabilitas mengalami penolakan ketika mendaftar di sekolah umum, dan diminta untuk bersekolah di Sekolah Luar Biasa (SLB). Alasan yang seringkali disampaikan pihak sekolah adalah keterbatasan tenaga pendidik serta sarana dan prasarana. Model pendidikan inklusif telah dibahas pada Konferensi Dunia tentangPendidikan Kebutuhan Khusus, yang dilaksanakan pada Juni 1994, para Menteri Pendidikan sedunia mendeklarasikan Salamanca Statement yang mengakui karakteristik khusus yang dimiliki setiap anak, menjamin hak setiap anak memperolah pendidikan, merekomendasikan agar sistem pendidikan dirancang untuk dapat mengakomodasi kebutuhan dan karakteristik anak yang sangat bervariasi, mendorong layanan pendidikan bagi anak berkebutuhan khusus secara inklusif di sekolah biasa, dan menegaskan bahwa pendidikan inklusif merupakan cara paling efektif untuk memerangi sikap diskriminatif prinsip dari pendidikan inklusif adalah selama memungkinkan, semua anak seyogyanya belajar bersamasama tanpa memandang kesulitan ataupun perbedaan yang mungkin ada pada mereka. Sapon-Shevin menjelaskan bahwa pendidikan inklusif merupakan sistem layanan pendidikan yang memungkinkan semua anak penyandang disabilitas mendapatkan pelayanan di sekolah-sekolah terdekat dan di kelas-kelas reguler, untuk itu dibutuhkan restrukturisasi sekolah, sehingga terbentuk komunitas yang mendukung pelaksanaan sistem tersebut, dan kebutuhan khusus anak penyandang disabilitas dapat terpenuhi. Dukungan ini tidak hanya dari pihak orang tua dan guru, tetapi juga dari anak penyandang disabilitas, teman-teman, dan masyarakat sekitar.

Keluarnya Deklarasi Universal Hak Asasi Manusia di dalam kovenankovenan internasional mengenai hak asasi manusia, telah memproklamasikan dan menyetujui bahwa setiap orang sangat berhak atas seluruh hak dan kebebasan 
sebagaimana yang telah diatur di dalamnya, tanpa perbedaan dalam bentuk apa pun, menegaskan kembali universalitas, ketidakterpisahkan, dan kesalingterkaitan dari semua hak asasi manusia dan merupakan suatu kebebasan fundamental yang dimiliki manusia. Kebutuhan bagi disabilitas untuk dijamin pemenuhan hak tanpa adanya diskriminasi merupakan suatu perwujudan keluarnya deklarasi tersebut.

Mengakui bahwa disabilitas merupakan konsep yang terus berkembang dewasa kini, merupakan salah satu bentuk usaha dalam melindungi hak-hak kaum disabilitas. Dengan mengakui bahwasanya disabilitas merupakan keterbatasan sosial, maka akan tercipta konsolidasi antara kaum disabilitas, pembuat kebijakan, dan penyedia pendidikan. Konsolidasi ini sangat diperlukan agar tercipta kesetaraan bagi penyandang disabilitas.

\section{Perlindungan Hukum dalam Pemenuhan Hak untuk Mendapatkan Pekerjaan bagi Penyandang Disabilitas}

Sebagai bentuk dari perlindungan hukum terhadap pemenuhan HAM di Indonesia khususnya terhadap hak untuk mendapatkan pekerjaan yang layak bagi disabilitas, Indonesia harus memiliki seperangkat peraturan hukum yang adil dan tegas dalam mengatur, aparat negara yang sigap dan pro disabilitas, dan masyarakat yang inklusif terhadap isu disabilitas.

Pengaturan tambahan yang dibuat berdasarkan kebutuhan penyandang disabilitas juga harus dapat dipertanggungjawabkan secara moral maupun hukum sebagaimana pengaturan kebijakan khusus lainnya. Secara moral tentu saja pengaturan tersebut haruslah sesuai dengan sila-sila dalam pancasila, yaitu Ketuhanan yang Maha Esa, Kemanusiaan yang adil dan Beradab, Persatuan Indonesia, Kerakyatan yang dipimpin oleh hikmat kebijaksanaan dan rahmat keadilan, dan keadilan sosial bagi seluruh rakyat Indonesia, dimana setiap sila menjiwai sila yang berada di atasnya.

Secara hukum, pengaturan ini tentu saja tidak dapat terlepas dari penjaminan konstitusi UUD NRI Tahun 1945 yang telah secara gamblang menjamin hak untuk mendapatkan pekerjaan bagi seluruh warga negara. Pengaturan lebih lanjut sebagai pengejahwantahan hak mendapat pekerjaan yang layak seperti UU No. 4 Tahun 1998 tentang Penyandang Cacat, UU No 13 Tahun 2003 tentang Ketenagakerjaan, UU No. 19 Tahun 2011 tentang Ratifikasi UNCRPD, dan UU No. 
8 Tahun 2016 tentang Penyandang Disabilitas, kesemuanya mengamanatkan agar penyandang disabilitas mendapatkan kesempatan kerja yang layak untuk penghidupannya. Semua pengaturan tersebut hanya menyebutkan hak untuk mendapatkan pekerjaan secara umum, namun tidak menjelaskan lebih lanjut bagaimana kemudian hak tersebut dapat diperoleh bagi seorang penyandang disabilitas.

Tingginya angka pengangguran di Indonesia atau sebanyak 7,39 juta jiwa menganggur berdasarkan data BPS 2014 lalu. Jumlah ini termasuk didalamnya penyandang disabilitas dan manusia normal. Berdasarkan teori batas bawah yang disinyalir Sjachran Basah ${ }^{9}$, maka seharusnya pengaturan tentang hak mendapatkan pekerjaan bagi disabilitas dapat dianggap menjadi bentuk eksklusifitas dari ranah hak asasi manusia yang harus dilindungi di Indonesia. Itu artinya bagi penyandang disabilitas hal tersebut merupakan sesuatu yang rawan akan perlakuan diskriminatif. Karena itu kebijakan afirmasi sangatlah diperlukan.

Pasal 28 I ayat (2) UUD NRI Tahun 1945 menyebutkan bahwa "setiap orang berhak bebas atas perlakuan yang bersifat diskriminatif atas dasar apa pun dan berhak mendapatkan perlindungan terhadap perlakuan yang bersifat diskriminatif itu". Kebijakan afirmasi atau diskriminasi positif merupakan kebijakan yang dibuat untuk melindungi hak kaum yang rawan mendapatkan diskriminasi, dan penyandang disabilitas merupakan salah satu kaum tersebut. Bentuk pengaturan tentang hak untuk mendapatkan pekerjaan bagi disabilitas dapat berupa jaminan maupun perlindungan. Salah satu bentuk kebijakan afirmasi yang ditawarkan peneliti adalah memberikan kuota 1\% pekerjaan sebagai Pegawai Negeri Sipil (PNS) bagi disabilitas. Kebijakan ini dianggap dapat memberikan win win solution baik bagi Pemerintah, masyarakat, maupun disabilitas itu sendiri.

Bagi disabilitas, tentu saja hal ini memudahkan dalam bersaing dengan berjuta-juta angkatan kerja yang juga mengincar PNS sebagai pekerjaan impiannya. Bagi Pemerintah, pemberian kuota kursi PNS ini dapat menyelesaikan masalah pertanggungjawaban negara terhadap warga negaranya, sekaligus mendapatkan tambahan sumber daya manusia (SDM) yang selama ini banyak

${ }^{9}$ Sjahran Basah, Perlindungan terhadap Sikap Tindak. Administrasi Negara, Alumni, Bandung, 1992, hlm. 12-14. 
mengisi angka pengangguran. Dengan majunya pemerintah sebagai agen perubahan dalam memperkerjakan penyandang disabilitas menjadi PNS, akan membuka mata perusahaan swasta agar ikut andil dalam memberdayakan SDM penyandang disabilitas.

Bagi masyarakat, terutama bagi mereka yang merupakan keluarga atau teman dari penyandang disabilitas akan merasakan manfaat dari adanya kuota tersebut. Keluarga atau teman mereka yang merupakan penyandang disabilitas yang selama ini tidak dapat bekerja untuk keluarganya, akan mendapatkan kesempatan lebih besar untuk bekerja dan tentu saja meringankan beban keluarga secara finansial. Masyarakat juga akan lebih perhatian terhadap isu disabilitas, karena kemungkinan berinteraksi semakin besar, sehingga kehidupan inklusi akan secara otomatis terbangun.

Konstitusi sudah dengan sangat tegas melindungi hak konstitusional penyandang disabilitas dalam konteks "setiap orang" maupun sebagai bagian dari "warga negara". Penyandang disabilitas juga dimungkinkan untuk mendapatkan affirmative action atau diskriminasi positif atas kemudahan dan perlakuan khusus dalam konteks pemenuhan hak konstitusionalnya tersebut.

Indonesia juga telah meratifikasi Convention on the Rights of Persons with Disabilities (selanjutnya disebut CRPD) ke dalam Undang Undang Nomor 19 Tahun 2011 (UU No. 19 Tahun 2011) tentang Ratifikasi CRPD. Implikasi formal dari ratifikasi tersebut adalah Indonesia harus mengambil segala upaya untuk mewujudkan secara optimal segala bentuk nilai yang tercantum dalam CRPD tersebut.Selain itu Indonesia juga memiliki 114 instrumen hukum terkait hak disabilitas dalam segala aspek kehidupan. ${ }^{10}$

Namun, berbagai instrumen hukum tentang hak disabilitas tersebut tidak terdapat korelasi antara satu dengan yang lainnya, sehingga tidak tercipta sistem yang terintegrasi untuk menciptakan kehidupan inklusi. Pengaturan tentang hak disabilitas tersebut juga cenderung berdasarkan belas kasihan (charity based) artinya kondisi seorang penyandang disabilitas dipaksakan untuk menyesuaikan kondisi

${ }^{10}$ Fajri Nursyamsi, dkk, Kerangka Hukum Disabilitas di Indonesia: Menuju Indonesia Ramah Disabilitas, Pusat Studi Hukum dan Kebijakan Indonesia, 2015, hlm. 25-30 
lingkungan dengan memberikan kompensasi atas disabilitas yang didapatkannya. Pasal 28 I ayat (2) UUD NRI Tahun 1945 menyebutkan bahwa "setiap orang berhak bebas atas perlakuan yang bersifat diskriminatif atas dasar apa pun dan berhak mendapatkan perlindungan terhadap perlakuan yang bersifat diskriminatif itu"

Kesempatan kerja bagi disabilitas seringkali menyebutkan syarat sehat fisik atau tidak cacat fisik untuk pelamarnya, hal ini merupakan salah satu bentuk diskriminasi ringan. Selanjutnya, dalam Pasal 3 ayat (3) UU No. 39 Tahun 1999 tentang Hak Asasi Manusia juga telah mempertegas larangan diskriminasi.

Kasus diskriminasi memang sangat jarang untuk dibawa ke ranah pengadilan negeri, padahal sejatinya suatu perkara dapat diselesaikan melalui dua tahapan, yaitu jalur litigasi dan jalur non litigasi. Pasal 13 UU No. 40 Tahun 2008 tentang Penghapusan Diskriminasi Ras dan Etnis telah memberikan penjelasan bahwa,“ Setiap orang berhak mengajukan gugatan ganti kerugian melalui pengadilan negeri atas tindakan diskriminasi ras dan etnis yang merugikan dirinya". ${ }^{11}$

Pemerintah Kota Surabaya pernah melakukan diskriminasi kepada penyandang disabilitas saat melakukan perekrutan Calon Pegawai Negeri Sipil (CPNS). ${ }^{12}$ Pemerintah, sebagai perwakilan negara seharusnya wajib membuat kebijakan anti diskriminasi, baik melalui peraturan perundang-undangan maupun dalam implementasinya. Pemerintah sebagai wakil negara, tidak boleh membuat kebijakan yang mengarah kepada perbuatan diskriminatif. ${ }^{13}$ Jika dengan kebijakan yang dibuatnya, sekelompok warga negara merasa terdiskriminasi, maka seharusnya peraturan tersebut ditinjau kembali, apalagi jika peraturan tersebut mengacu kepada keterbatasan fisik seseorang. Padahal, keterbatasan fisik tidaklah mengurangi kecerdasan dan kapasitas seseorang untuk diperlakukan sama di hadapan hukum. ${ }^{14}$

Menurut Hart, ${ }^{15}$ bahwa adil dan tidak adil merupakan bentuk kritikan moral yang lebih spesifik dari pada baik dan buruk atau benar dan salah, terlihat jelas

${ }^{11}$ Lihat, Pasal 13 UU No. 40 Tahun 2008 tentang Penghapusan Diskriminasi Ras dan Etnis

${ }^{12}$ Zainal Abidin Pakpahan, dkk, "Analisis Yuridis atas Tindakan Diskriminatif sebagai Pelanggaran HAM Ringan Berdasarkan Undang-Undang No. 40 Tahun 2008 tentang Penghapusan Diskriminasi Ras dan Etnis”, USU Law Jurnal, Volume II Nomor 2, Fakultas Hukum Universitas Sumatera Utara, Medan, 2013, hlm. 125

${ }^{13}$ Lihat, Pasal 28I ayat (4) UUD NRI Tahun 1945

${ }^{14}$ Lihat, Pasal 28D ayat (1) UUD NRI Tahun 1945

15Petrus C.K.L. Bello, Hukum dan Moralitas, Erlangga, Jakarta, 2012, hlm. 39. 
dari fakta bahwa secara logis mengklaim sebuah hukum adalah baik karena hukum itu adil, atau bahwa hukum itu buruk karena tidak adil. Hart, menjelaskan konsep umum keadilan yang selalu berkaitan dengan kewajaran (fairness), sehingga sebuah keputusan dinilai berdasarkan "wajar" atau "tidak wajar". Praktik sosial menjadi penting bagi terwujudnya hukum itu.

Ketika hukum mengacu kepada irelevansi yang nyata seperti tinggi badan, fisik, bobot atau kecantikan, maka hukum akan menjadi tidak adil sekaligus menggelikan. ${ }^{16}$ kasus yang terjadu pada seorang penyandang disabilitas yang diperlakukan secara diskriminatif oleh pemerintah Kota Surabaya, dengan ditolak untuk mendaftar sebagai Calon Pegawai Negeri Sipil (CPNS). Pemerintah Kota Surabaya (Pemkot Surabaya) memiliki interpretasi tentang syarat pendaftaran sehat jasmani dan rohani, sebagai tidak cacat (disabilitas), sehingga Wuri Handayani ${ }^{17}$ yang menggunakan kursi roda, tidaklah memenuhi syarat untuk mendaftar sebagai CPNS. Akhirnya, korban melayangkan gugatan atas perlakuan diskriminasi yang dilakukan oleh Pemkot Surabaya kepada Pengadilan Tata Usaha Negara (PTUN) Surabaya pada Februari 2005.

Putusan PTUN Surabaya memutuskan bahwa interpretasi Pemkot Surabaya terbukti salah dan mengabulkan gugatan Wuri. ${ }^{18}$ Tidak terima dengan putusan PTUN Surabaya, Pemkot Surabaya lalu mengajukan kasasi kepada Mahkamah Agung (MA). Wuri lalu memenangkan kasus tersebut pada tanggal 8 Desember 2009 berdasarkan surat Nomor Register 595/K/TUN/2005. Tindakan Pemerintah Surabaya yang menolak Wuri Handayani terbukti telah memenuhi unsur pidana dalam Pasal 15 UU Nomor 40 Tahun 2008 tentang Penghapusan Diskriminasi Ras dan Etnis, dikarenakan Walikota Surabaya, Bambang DH, melanggar HAM dari penyandang disabilitas untuk mendapatkan pekerjaan dan penghidupan yang layak. $^{19}$

\footnotetext{
${ }^{16}$ Ibid.

${ }^{17}$ Korban yang mengalami tindakan diskriminatif pada saat pemerintah Kota Surabaya tidak memperkenankan dirinya saat mengikuti seleksi CPNS di karenakan penyandang disabilitas. "Wawancara" dengan Sasanti Staf Komnas HAM Republik Indonesia, 23 Mei 2013.

${ }^{18}$ Zainal Abidin Pakpahan, dkk, Analisis Yuridis..., Op. Cit., hlm. 140

${ }^{19}$ Cityserum.com, Sengketa dengan Penyandang Cacat, Kasasi Pemkot Surabaya ditolak MA, dalam http:/ / city.seruu.com/read/2009/12/15/10835/sengketa-dengan-penyandang-cacat-kasasi-pemkotsurabayaditolak-ma, diakses 29 April 2016
} 
Menurut Wuri Handayani, putusan MA tersebut merupakan pertama kalinya MA memberikan keputusan yang adil terhadap penyandang cacat mengingat selama ini para penyandang cacat selalu kesulitan dalam mencari pekerjaan baik dimana saja, ${ }^{20}$ baik itu di lingkungan pemerintah maupun swasta. Keluarnya putusan tersebut menjadi angin segar bagi disabilitas, karena putusan tersebut dapat menjadi yurisprudensi atas penolakan untuk bekerja karena persyaratan sehat jasmani dan rohani. Dengan adanya putusan itu para penyandang cacat berhak untuk mendapatkan semuanya layaknya mereka yang tidak cacat. $^{21}$

\section{Formulasi Kebijakan Affirmative Action untuk Aksesibilitas Pendidikan dan Pekerjaan Bagi Disabilitas di Indonesia}

Kebijakan afirmasi (affirmative action) merupakan salah satu solusi untuk menyelesaikan masalah diskriminasi yang dilakukan oleh negara terhadap kaum disabilitas. Seperti telah disebutkan pada sub bab sebelumnya bahwa ada tiga cara untuk memberikan kebijakan tersebut, yaitu: (i) Melalui undang-undang khusus tentang kuota; (ii) Melalui undang-undang khusus; dan (iii) Perusahaan dapat memiliki kebijakan untuk kuota secara informal.

Dalam penelitian kali ini, peneliti mencoba untuk memformulasikan regulasi berbentuk undang-undang khusus tentang pekerjaan bagi disabilitas di Indonesia. ${ }^{22}$ Tentu saja peneliti akan kembali merujuk kepada Fair Work Act 2009 yang dimiliki oleh negara Australia. Untuk itu terlebih dahulu peneliti akan membahas substansi apa saja yang harus ada dalam regulasi tersebut, juga dengan menganalisis. Peneliti juga akan membahas pemberian kuota untuk pekerjaan sektor Pemerintahan, Pemerintahan Daerah, BUMN, dan BUMD, juga dalam sektor perusahaan swasta.

Sebuah undang-undang haruslah muncul dari kebutuhan akan pengaturan di masyarakat. Berdasarkan Pasal 10 ayat (1) UU No. 12 Tahun 2011 tentang

${ }^{20} \mathrm{Ibid}$

${ }^{21}$ Wuri Handayani, korban perlakuan diskriminatif berdasarkan penyandang disabilitas di Kota Surabaya, pada saat dirinya ditolak untuk mendaftar sebagai Calon Pegawai Negeri Sipil. Yurisprudensi ini menarik jika dibandingkan dengan 2 (dua) hasil penelitian di sektor swasta, Lihat pada Suhartoyo, "Perlindungan Hukum terhadap Pekerja/Buruh Penyandang Disabilitas Di Indonesia", Masalah-Masalah Hukum, Vol. 43 No. 4 Oktober 2014, hlm. 468 dan 472-477.; Lita Tyesta ALW., "Prospek Perlindungan Penyandang DisabilitasTerhadap Perilaku Diskriminatif di Kota Semarang", Masalah-Masalah Hukum, Vol. 44 No. 3 Juli 2015, hlm. 253 dan 263

22 Sedangkan untk regulasi daam bentuk Perda terkait dengan masalah kebijakan afirmatif ini, menarik untuk dibaca tulisan: Zulfah Latuconsina, "Afirmasi Kebijakan Pemerintah dalam Fasilitasi Kerja bagi Penyandang Disabilitas”, Jurnal Pandecta, Volume 9, Nomor 2, Januari 2014, hlm. 205-208. 
Pembentukan Peraturan Perundang-undangan terdapat berbagai materi muatan yang harus diatur dengan undang-undang, hal tersebut antara lain: a. Pengaturan lebih lanjut mengenai ketentuan UUD NRI Tahun 1945; b. Perintah suatu Undang-Undang untuk diatur dengan Undang-Undang;c. Pengesahan perjanjian internasional tertentu; d. Tindak lanjut atas putusan Mahkamah Konstitusi; dan/atau e. Pemenuhan kebutuhan hukum dalam masyarakat. ${ }^{23}$

Undang-undang pekerjaan bagi disabilitas yang akan peneliti rumuskan ini merupakan bentuk pemenuhan kebutuhan hukum dalam masyarakat, karena hingga kini belum terdapat undang-undang khusus yang mengatur aksesibilitas penyandang disabilitas untuk mendapatkan pekerjaan di Indonesia. Selain itu, pembentukan undang-undang pekerjaan bagi disabilitas ini juga sebagai tindak lanjut dari putusan MK No.143/PUU-VII/2009 perihal Pengujian Undang-Undang Nomor 19 Tahun 2008 tentang Surat Berharga Syariah Negara terhadap UndangUndang Dasar Negara Republik Indonesia Tahun 1945.

\section{Jangkauan dan Ruang Lingkup Materi Muatan Undang-Undang}

1. Prinsip-prinsip Utama Mengenai Penyandang disabilitas:24 a. Aksesibilitas b.

Dukungan dan Penyesuaian yang Sewajarnya (Reasonable Accomodation)25; c. Mengukur Derajat Disabilitas.

2. Hak atas Pekerjaan yang layak: a. Kerja dan Kesempatan Kerja; b. Rekomendasi ILO No. 168; c. Kemampuan untuk Dipekerjakan dan Kepentingan Dunia Usaha

Diberikannya kuota sebanyak $1 \%$ untuk bekerja di penerimaan pekerja dalam sektor Pemerintahan, Pemerintahan Daerah, BUMN, dan BUMD sebagai PNS sebanyak 1\% merupakan gagasan yang diberikan oleh penulis mengingat bahwa di Indonesia, penyandang disabilitas masih rawan terhadap tindakan diskriminasi, sehingga dibutuhkan kebijakan yang tidak hanya menjamin tapi juga melindungi hak-hak disabilitas untuk mendapatkan pekerjaan. Kuota sebanyak 1\% dipilih oleh peneliti sebagai bentuk lanjutan dari UU No. 4 Tahun 1997 tentang Penyandang Cacat terutama dalam penjelasan Pasal 14.

${ }^{23}$ Lihat, Pasal 10 UU Nomor 12 Tahun 2011 tentang Pembentukan Peraturan Perundang-undangan

${ }^{24}$ ILO, Mempromosikan Pekerjaan Layak Bagi Semua Orang: Membuka Kesempatan pelatihan dan Kerja bagi Penyandang Disabilitas, reader kit yang dibagikan dalam Lokakarya Nasional dijakarta, hlm. 20

${ }^{25}$ ILO, Mempromosikan..., Ibid., hlm. 26 
Secara matematis, jika dihitung dari jumlah angkatan kerja di Indonesia, yaitu sebanyak 103, 97 juta jiwa (dihitung pada akhir Tahun 2014) ${ }^{26}$ atau sebanyak $66,43 \%$ dari jumlah seluruh penduduk Indonesia, sedangkan jumlah penyandang disabilitas berdasarkan sensus terkahir pada Tahun 2010 adalah sebanyak 24 juta jiwa atau sebanyak 10\% dari jumlah seluruh penduduk di Indonesia. Jika diibaratkan seluruh jumlah penyandang disabilitas adalah angkatan kerja dengan kemungkinan penambahan laju penduduk sebanyak 2\% setiap Tahunnya, maka didapatkan jumlah angkatan kerja disabilitas sebanyak 10,3\% dari total jumlah seluruh angkatan kerja. Maka Negara dapat mengutamakan setidak-tidaknya kuota sebanyak $1 \%$ atau lebih sesuai dengan kompetensi yang diperlukan oleh Pemerintah, Pemerintah Daerah, BUMN, dan BUMD, sehingga dapat membuka peluang pada penyandang disabilitas dan untuk menambah Sumber Daya Manusia (SDM) penyandang disabilitas yang selama ini hidup dalam ketergantungan pada orang lain.

Peraturan yang baik adalah peraturan yang bermanfaat bagi hajat hidup masyarakat. Pembentukan Undang-Undang tentang Pekerjaan bagi Disabilitas diharapkan dapat menjadi karya yang bermanfaat bagi masyarakat luas, khususnya penyandang disabilitas, pembuat kebijakan, dan para akademisi sebagai khasanah ilmu pengetahuan.

Untuk mempermudah pembaca seperti apa bentuk perlindungan hukum Indonesia kepada penyandang disabilitas oleh pemerintah hendaknya mendapatkan pendidikan dan pekerjaan yang layak sebagai berikut:

${ }^{26}$ Badan Pusat Statistik, Data Jumlah Angkatan Kerja, Penduduk Bekerja, Pengangguran, TPAK, dan TPK, 1986 2013, https://www.bps.go.id/linkTabelStatis/view/id/973, diakses 31 Juli 2016. 
Tabel 2

Bentuk Perlindungan Hukum Disabilitas

\begin{tabular}{|c|c|c|c|}
\hline No. & Perbedaan & Hak Pendidikan & Hak Pekerjaan \\
\hline \multirow[t]{5}{*}{1.} & Dasar Hukum & UUD NRI Tahun 1945: & UUD NRI Tahun \\
\hline & & Pasal 31 ayat (1) & $\begin{array}{l}\text { 1945: Pasal } 27 \text { ayat } \\
\text { (2) }\end{array}$ \\
\hline & & Dijabarkan melalui UU & \\
\hline & & Nomor 20 Tahun 2003 tentang & \\
\hline & & Sistem Pendidikan Nasional & \\
\hline \multirow[t]{2}{*}{2.} & Paradigma & Keterbatasan sosial, & Keterbatasan sosial, \\
\hline & Disabilitas & pendekatan sosial diperlukan & $\begin{array}{l}\text { pendekatan sosial } \\
\text { diperlukan }\end{array}$ \\
\hline \multirow[t]{3}{*}{3.} & Formulasi & Pendidikan inklusi dengan & Pengaturan hukum \\
\hline & Kebijakan & mendirikan PTLB & tentang sistem \\
\hline & & & $\begin{array}{l}\text { kuota pekerjaan } \\
\text { pada PNS }\end{array}$ \\
\hline
\end{tabular}

Sumber: Diolah dari berbagai data oleh Penulis

\section{Penutup}

Berdasarkan pembahasan yang peneliti jabarkan di atas, maka kesimpulannya adalah sebagai berikut: Pertama, pemerintah terkesan masih memberikan perlindungan hukum secara diskriminatif terhadap penyandang disabilitas untuk memperoleh pendidikan dan pekerjaan yang layak. Meskipun regulasi tentang ini sudah cukup lengkap pada level UUD NRI Tahun 1945 dan UU. Kedua, Sedangkan regulasi pada level Perdanya dari masing-masing daerah. Ada beberapa kekaburan norma hukum dalam peraturan yang mengatur khusus tentang aksesibilitas pendidikan dan pekerjaan bagi penyandang disabilitas. Dalam hal ini telah dilakukan pembaharuan hukum berupa kebijakan affirmative action bidang aksesibilitas pendidikan dan pekerjaan bagi disabilitas, meliputi: 1) Menyempurnakan (membuat sesuatu yang lebih baik); 2) mengubah agar jauh lebih baik; 3) Mengadakan sesuatu yang sebelumnya belum ada.

Saran berkenaan dengan tanggung jawab negara terhadap pemenuhan hak untuk mendapatkan pekerjaan bagi disabilitas, yaitu: a. Penyandang disabilitas harus optimis untuk mendapatkan kesempatan melanjutkan pendidikan setinggitingginya dengan harapan berkesempatan mendapatkan pekerjaan yang layak pada sektor negara maupun swasta. b. Pemerintah, Pengusaha, LSM, dan 
Kelompok Profesi, harus menempatkan kelompok penyandang disabilitas menjadi layaknya teman sendiri, penuh empati, dan memfasilitasi sesuai kapabilitas dan kompetensiya masing-masing. Masyarakat juga harus mendorong keluarga dan teman-temannya penyandang disabilitasnya untuk ikut berperan aktif dalam menciptakan pekerjaan bagi kehidupan mereka yang lebih layak. c. Para penyandang disailitas dalam memperjuangkan hak-haknya, perlu bantuan hukum dalam upayanya untuk memperoleh ha-haknya juga dalam menyelesaikan perkara yang mungkin dihadapinya baik melalui jalur litigasi dan litigasi. ${ }^{27}$

\section{Daftar Pustaka}

\section{Buku}

Asshiddiqie, Jimly, Pengantar Ilmu Hukum Tata Negara Jilid 2, Sekretaris Jenderal dan Kepaniteraan Mahkamah Konstitusi, Jakarta, 2006.

Basah, Sjahran Perlindungan Terhadap Sikap-Tindak Administrasi Negara, Alumni, Bandung, 1992.

Kamus Besar Hukum Indonesia Edisi keempat Departemen Pendidikan Nasional, PT Gramedia Pustaka Utama, Jakarta, 2008.

Nursyamsi, Fajri, dkk, Kerangka Hukum Disabilitas di Indonesia: Menuju Indonesia Ramah Disabilitas, Pusat Studi Hukum dan Kebijakan Indonesia, 2015.

Syahbuddin Latief, M., Jalan Kemanusiaan, Panduan untuk Memperkuat Hak Asasi Manusia, Lapera Pustaka Utama, Yogyakarta, 1999.

\section{Jurnal dan Makalah}

Abidin Pakpahan, Zainal, dkk, "Analisis Yuridis atas Tindakan Diskriminatif seagai Pelanggaran Ham Ringan Berdasarkan Undang-Undang No. 40 Tahun 2008 tentang Penghapusan Diskriminasi Ras dan Etnis", USU Law Jurnal, Volume II Nomor 2, 2013.

ILO, Mempromosikan Pekerjaan Layak Bagi Semua Orang: Membuka Kesempatan pelatihan dan Kerja bagi Penyandang Disabilitas, reader kit yang dibagikan dalam Lokakarya Nasional di Jakarta.

Latuconcina, Zulfatah, "Afirmasi Kebijakan Pemerintah Dalam Fasilitasi Kerja bagi Penyandang Disabilitas", Pandecta Jurnal Unnes, Volume 9. Nomor 2. Januari 2014, Semarang, 2014.

Malinda, Anggun, Ekha Nurfitriana, dan M Yasin Al-Arif, Bantuan Hukum Terhadap Kaum Difabel Korban Tindak Pidana Upaya Mewujudkan Acces

${ }^{27}$ Lihat Anggun Malinda, Ekha Nurfitriana, dan M Yasin Al-Arif, "Bantuan Hukum Terhadap Kaum Difabel Korban Tindak Pidana Upaya Mewujudkan Acces to Justice”, Jurnal Hukum IUS QUIA IUSTUM No. 3 Vol. 21 Juli 2014, hlm. 465. 
to Justice, Jurnal Hukum IUS QUIA IUSTUM No. 3 Vol. 21 Juli 2014, UII Yogyakarta, 2014.

Ridlwan, Zulkarnain, Pelindungan Hukum Hak-hak Knstitusional Penyandang Disabilitas (Rights of Persons With Disabilities), Fiat Justisia Jurnal Ilmu Hukum, Volume 7. N0. 2, Mei-Agustus 2013.

Suhartoyo, "Perlindungan hukum terhadap Pekerja/Buruh Penyandang Disabilitas di Indonesia", Masalah-Masalah Hukum Vol. 43 No. 4 Oktober 2014.

Tyesta ALW., Lita, Prospek Perlindungan Penyandang Disabilitas Terhadap Perilaku Diskriminatif Di Kota Semarang, Masalah Masalah Hukum Vol. 44 No. 3 Juli 2015.

\section{Peraturan Perundang-undangan}

Undang-Undang Dasar Negara Republik Indonesia Tahun 1945

Undang-Undang Nomor 4 Tahun 1997 tentang Penyandang Cacat (Lembaran Negara Republik Indonesia Tahun 1997 Nomor 9, Tambahan Lembaran Negara Republik Indonesia Nomor 3670)

Undang-Undang Nomor 13 Tahun 2003 tentang Ketenagakerjaan (Tambahan Lembaran Negara Republik Indonesia Tahun 2003 Nomor 39, Tambahan Lembaran Negara Republik Indonesia Nomor 4279)

Undang-Undang Nomor 11 Tahun 2005 tentang Pengesahan Kovenan Internasional tentang Hak-Hak Ekonomi, Sosial, dan Budaya (Lembaran Negara Republik Indonesia Tahun 2005 Nomor 118, Tambahan Lembaran Negara Republik Indonesia Nomor 4557)

Undang-Undang Nomor 17 Tahun 2008 tentang Pelayaran (Lembaran Negara Republik Indonesia Tahun 2008 Nomor 64, Tambahan Lembaran Negara Republik Indonesia Nomor 4849)

Undang-Undang Nomor 12 Tahun 2011 tentang Pembentukan Peraturan Perundang-undangan (Lembaran Negara Republik Indonesia Tahun 2011 Nomor 82, Tambahan Lembaran Negara Republik Indonesia Nomor 5234)

\section{Internet}

Cityserum.com, Sengketa dengan Penyandang Cacat, Kasasi Pemkot Surabaya ditolak MA, dalam http://city.serUndang-Undang.com/read/2009/12/ 15/10835/sengketa-dengan-penyandang-cacat-kasasi-pemkotsurabayaditolak-ma, diakses 29 April 2016

ILO.org, The International Labour Organization Ability Asia Pacific, dalam http://www.ilo.org/public/english/region/asro/bangkok/ability/inde x.htm, diakses 29 April 2016

Kementrian Pemberdayaan Perempuan dan Perlindungan Anak, Jumlah Penyandang Disabilitas di Indonesia www.kemenpppa.go.id/index.php/ data-summary/profile-perempuan-indonesia / 641-penyandangdisabilitas diakses 2 Januari 2016. 